\title{
Ellipsis
}

2014

\section{Sleeping Beauty through the Ages}

Sarah Semsar

Follow this and additional works at: https://scholarworks.uno.edu/ellipsis

Part of the Comparative Literature Commons

\section{Recommended Citation}

Semsar, Sarah (2014) "Sleeping Beauty through the Ages," Ellipsis: Vol. 41 , Article 31.

DOI: https://doi.org/10.46428/ejail.41.31

Available at: https://scholarworks.uno.edu/ellipsis/vol41/iss1/31

This Literary Criticism is brought to you for free and open access by the Department of English and Foreign Languages at ScholarWorks@UNO. It has been accepted for inclusion in Ellipsis by an authorized editor of ScholarWorks@UNO. For more information, please contact scholarworks@uno.edu. 


\title{
Sleeping Beauty through the Ages
}

Sarah S. Semsar

\author{
The Quarante Club Prize
}

Fairy tales have been with the world arguably since the beginning of time. They come in many forms, from many places, yet somehow they all share similar elements that place them in a special category within the literary world. Historically, they have evolved from oral traditions of storytelling with goals of passing down ancient, common, and social knowledge to major published and cinematic works. In the past "elders delivered these stories, the literate used them for entertainment, and the illiterate often looked to them as a sort of moral compass" or a way to understand the ever-evolving world (Auerbach 11).

When considering the various versions of the tale of Sleeping Beauty, it becomes essential to search for feminist elements and gender roles illustrated in the texts throughout time. Using Charles Perrault's "The Sleeping Beauty in the Wood" as a foundation for a fairly traditional patriarchal view, indicative of the era prior to the first wave feminist movement from a U.S. perspective, we see specific gender and commentary on general societal norms. Anne Thackeray Ritchie's Victorian-era version of Sleeping Beauty, found in Nina Auerbach's collection of Victorian women's fairy tales, represents an example of first-wave feminism in fairytale literature. Additionally, Angela Carter's version of Sleeping Beauty, "The Lady of the House of Love," could easily be described as a secondwave feminist piece. Juxtaposing these tales and using critical analysis and criticism from the texts and other scholarly sources illustrates that fairy tales (and the time in which they are presented) are reflections of a society's social norms and offer commentary on gender roles and values of the heroine and other subordinate characters. Furthermore, by examining the similarities and differences of the versions, and exploring the evolution of these pieces as a whole, it becomes evident that these tales represent some structure of human nature, which does not appear to evolve much throughout history.

Charles Perrault's "The Sleeping Beauty in the Wood," published in France in 1697, reflects many of society's traditional patriarchal values of the era. The young fifteen-year-old princess is sentenced to a very long arranged marriage engagement magically preordained by the good fairy. After one hundred years, her prince arrives and breaks the sleeping curse brought on by her deadly female 
curiosity. The prince instantly loves her because she has the "disposition of an angel," is the most beautiful woman in the world, and has a magical and sweetly soft voice (Perrault). This illustrates many ideals held by men of the $17^{\text {th }}$ century. Women were expected to remain humble, to tend to their households, to help with labor (depending on their social status), to be subservient to male authority, and most importantly, to remain chaste and faithful to their husbands for reproductive legitimacy purposes.

In a classic patriarchal societal structure, a newlywed woman was expected to leave her family and live with her husband and his family. The circumstance could sow fear and resentment on both sides of the family. Suddenly, there is another mouth to feed in the eyes of the husband's family. The wife would feel as if she were isolated, maybe even mere property in some instances. Perrault depicts this fear and resentment in his tale when the princess moves to the young king's castle and has to live with his scary cannibal ogre of a mother.

Perrault also fills his version with rich magical and romanticized imagery and gender-specific themes and commentary. The presence of actual faeries or magical beings is represented, numerology is present as emphasis is given to the number of faeries mentioned, as well as the age of the princess, and the number of years required of her to sleep when the curse commences. In classic literary form, there is a rite of passage element present. In this version, the princess initiates her curse by being curious and speaking to an elderly spinster woman of an obviously lower social status than her own. After some time in deep stasis, when she is ripe and ready for her prince, she is awakened physically, emotionally, and sexually as she soon marries and consummates her marriage. Culturally, this suggests that Europeans of this era encouraged the use of arranged marriages with perhaps "lengthy engagements." Marriage was a social and economic contract that ensured offspring, and by having a pure virgin woman of the same social status, the prince, too, was able to fulfill his destiny and obligations. Perrault's tale is not only about the woman's roles in society, but rather the role men were supposed to play as well.

When examining Anne Thackeray Ritchie's "The Sleeping Beauty in the Wood," themes of early feminist responses to English Victorian-era social constructs are certainly present. Ritchie's piece was published in the mid to late 1800s. Although primarily traditional, some elements of a first-wave feminist perspective are present. According to Dr. Susan Mann, the first wave of feminism "focused primarily on the surge of women's rights activism beginning in the 1830s" (415). Some of these rights petitioned for included the right to not be civilly dead if married, the right to obtaining an education, the right to vote, and childcare rights if divorced. In Ritchie's "Sleeping Beauty," we see her commentary and obvious distaste with dull Victorian-era social structure for 
women. Cecelia's 'sleeping curse' is her confined civility and lack of socialization with the opposite sex or even the same sex. Cecelia has lived twentyfive years full of isolation and rigid social decorum training. Ritchie depicts her day as a boring and rigidly structured event full of "dinner bells" and passionless practicing of piano playing. Critic Manuela Mouroa argues that although "Ritchie never openly embraced a feminist identity," she explores the social conditioning of Victoria-era women (57). Some may find her piece mind numbing, yet it is a culturally reflective portrayal of Victorian ideals of marriage and domesticity.

There are various gender-specific themes and imagery present in Ritchie's "Sleeping Beauty." Ritchie carefully portrays the social position of unmarried women in a more constructive light. For example, she challenges the idea of an unmarried spinster woman as pathetic and makes her a sort of bold fairy godmother character. In Richie's story, the spinster plays more of a matchmaker role for Cecilia and her prince. Ritchie creates "strong-willed independent women characters" more capable of decision-making (Mouroa 58). There is also strong commentary on isolation and the effects it has on a woman's emotional health. Cecelia is confined to the dim grey mansion and lacks an understanding of beauty trends. In her portrayal of Cecelia, "Ritchie mocks the female passivity that so attracted Victorian males to the sleeping beauties they tried to awaken with a kiss" (Auerbach 15). Throughout the piece, it is evident that Cecelia is moderately against the idea of marriage and suggests that "she may not ever marry." However, in the end, she embraces traditional female roles and seeks a husband and has a family.

British author Angela Carter's "The Lady of the House of Love" was published in 1979 during the second wave of feminism. The second wave encompassed the resurgence of feminist activism akin to the 1960s to the 1970s. Second wavers championed for paid maternity leave, subsidized childcare, educational opportunities, and equal employment opportunities. (Mann 424) In Carter's "Lady" we see a very modern Gothic text in style. It is full of rich, dark magical imagery as well as commentary on social positioning of women and men's gender roles. The Countess has grown up relatively alone in almost utter isolation. Her only companion is a caged bird, a lark that sings mostly out of utter fright. Her "keeper" is an old woman who is essentially mute throughout the text but keeps the Countess within the confines of her social position and encourages her to follow the traditions of her family's horrific past. Unlike all of the other previous Sleeping Beauties, the Countess is literally among the living dead. Her female passivity is significantly less than the other princesses.

Some critics suggest that Carter creates "a clever female heroine who escapes by her own wits," one that takes her own life and sexuality into her own hands (Orenstien). It is the Countess's lack of civility and her obvious lack of being a glamorous victim that sets her apart from the other Beauties. In Carter's 
"Lady," the male protagonist is actually the glamorous victim character so often found in traditional fairy tales. She reverses gender roles in a way and reclaims femininity in a shocking almost animalistic way. The Countess preys on men for her survival. The bicyclist (or prince in this version) is the chaste, virginal, and innocent one. The prince describes the Countess as having an almost whorish attraction about her. Literally, he says that she is "pathetic looking" and has the "mouth of a whore" (Carter 100). The Countess experiences moments and daily tests of self-reliance, as she is living independently and tries to support herself. This theme is something many second wavers identified closely with. Women felt that they needed the opportunities to support themselves financially, educationally, and socially as their male counterparts could so easily do.

Critic Catherine Orenstein suggests that the Countess is going on a sort of "wisdom journey" and develops her personal social identity. Although she is isolated throughout much of the piece, her isolation seems to be in response to her awareness of being different, a social outcast almost for being less passive. Carter employs much vivid Gothic imagery throughout the text. Arguably, the images of the roses and rose bushes represent her sexuality and sinful nature (Sheets 642). The obvious element of vampirism within a gendered context could suggest the succubus theme. It seems that any woman, if empowered, is the enemy. The Countess is supposed to be a ravenous beast, a trickster, and a whore due to her lack of female passivity.

Each of these pieces reflects the society and cultural norms of their era. In Perrault's version, there are clear classical pre-revolutionary ideas of patriarchy and gender-specific ideals of female passivity. In Ritchie's "Sleeping Beauty," the heroine emits a stronger sense of self and speaks out to her elder's about her wishes, yet she still submits to society's demands. Ritchie's piece is one of early feminist post-Victorian thinking. Carter's piece is undoubtedly the most shocking, grotesque, and forward of the works. She employs various literary methods and devices to illustrate her distaste with cultural norms and obvious gendering. These works depict the society's values, norms, and customs of their era. They illustrate responses to budding social movements and reformation, signaling some changes. The issue, however, is that society has not evolved too much since the late $17^{\text {th }}$ century. If many of the themes and images have remained true to today, human nature has not evolved greatly. 


\section{Works Cited}

Auerbach, Nina, and U. C. Knoepflmacher. Forbidden Journeys: Fairy Tales and Fantasies by Victorian Women Writers. Chicago: University of Chicago, 1992. 1-21. Print.

Carter, Angela. "The Lady of the House of Love." The Bloody Chamber. New ed. New York: Harper \& Row, 1979. 93-107. Print.

Mann, Susan Archer. Doing Feminist Theory: From Modernity to Postmodernity. 1st ed. Oxford: Oxford UP, 2012. 72-78. 413-423. Print.

Mourao, Manuela. "Negotiating Victorian Feminism: Anne Thackeray Ritchie's Short Fiction." Tulsa Studies in Women's Literature ns 20.1 (2001): 57-58. JSTOR. Web. 12 Apr. 2013. <http://www.jstor.org/stable/464467>.

Orenstein, Catherine. "Dances With Wolves: Social and Sexual Messages of Fairy Tales." Ms. Magazine. N.p., Summer 2004. Web. 08 Mar. 2013. $<$ http://www.msmagazine.com/summer2004/danceswithwolves.asp>.

Perrault, Charles. "The Sleeping Beauty in the Wood." Folk \& Fairy Tales. By Martin Hallett and Barbara Karasek. 4th ed. Peterborough, Ont.: Broadview, 2009. 71-77. Print.

Sheets, Robin Anne. "Pornography, Fairy Tales, and Feminism: Angela Carter's "The Bloody Chamber"" Journal of the History of Sexuality 1.4 (1991): 633-57. JSTOR. Web. 2 May 2013. $<$ http://www.jstor.org/stable/3704419>.

Thackeray Ritchie, Anne. "The Sleeping Beauty in the Wood." Forbidden Journeys: Fairy Tales and Fantasies by Victorian Women Writers. By Nina Auerbach and U. C. Knoepflmacher. Chicago: University of Chicago, 1992. 21-34. Print. 